\title{
Methods of Learning English Skills outside Classroom of Students: A Case Study in Vietnam
}

\author{
MA. Trinh Thi Thanh Thuy*, MA. Nguyen An Giang \\ Department of English languages Trade Union University, Vietnam
}

*Corresponding Author: MA. Trinh Thi Thanh Thuy, Department of English languages Trade Union University, Vietnam

\begin{abstract}
This research looks into the methods that university students employed in their after-class practice and the factors affecting their options of those methods. An English questionnaire was designed to collect data on the most popular methods that they adopted to learn four skills: reading, writing, speaking and listening outside classroom, the frequency of using and the reason why they choose these methods. It has been revealed that students regularly exploited a variety of methods, such as doing reading and listening sections, free-writing about any topics, self-talking in order to polish skills. On the other hand, other useful methods such as talking to foreigners, reading literature works, group study or listening to radio are not highly appreciated. Generally, students' allotted time and test format at Trade Union University, Vietnam had the greatest impact on first year students' decision in utilizing certain learning methods. It is recommended that a wide range of helpful methods should be applied, which will contribute to students' acquisition of English.
\end{abstract}

Key terms: skills, university students, learning, outside classroom.

\section{INTRODUCTION}

To master a foreign language, practicing frequently to form "skills" plays an important role. However, exploiting the appropriate methods to improve English skills is a matter of deep concerns of many students. According to previous study, regular practicing of English both in and, particularly, after class could drive students to their peak performance [1]. Therefore, it is essential to find out suitable methods for practicing, which is a focus of preceding research in the world. However, in Vietnam, language learning strategies had not been sufficiently paid attention to [2]. To investigate thoroughly this matter, a research was carried out to discover the useful methods of learning four English skills: reading, writing, listening and speaking outside classroom among English lessons at Trade Union University. It focused on discovering whether students had suitable learning methods, which methods were employed to accelerate study progress, the regularity of using these methods after school as well as what factors influenced students' options.

\section{Materials And Methods}

To collect data for the study, a questionnaire in English was developed. The questions were designed to find out if students formed their learning methods, what methods and how frequently they were used outside classroom together with why students selected those methods. A survey was carried out four hundreds seventy five at forty five classes of Trade Union University. Any queries or misunderstandings were fully answered before students progressed to finishing the questionnaire. All the handouts were collected 20 minutes later for the next processing.

\section{Results}

\subsection{Current State of Forming Suitable Methods for Learning English Outside Classroom at Trade Union University}

The investigation shows that the number of students who had suitable methods for learning English skills outside classroom appears to be dominant. As shown in chart 1, the percentage of students who formed their own learning methods $(75 \%)$ is three times greater than that of students who did not have and were not sure $(15 \%$ and $10 \%)$. 


\subsection{Methods for Learning Four English Skills Outside Classroom of Students}

\subsubsection{Reading Skill}

Doing reading exercises seems to be the most popular method of all. Chart 1 shows that approximately 100 per cent of asked students chose reading exercises. 92\% students regularly practiced doing reading sections. This skill can be explained by the format of reading test at Trade Union University and the reputation of international tests. In contrast, students rarely turned to newspapers, journals to progress reading competence with $5 \%$ and $22 \%$ of students respectively.

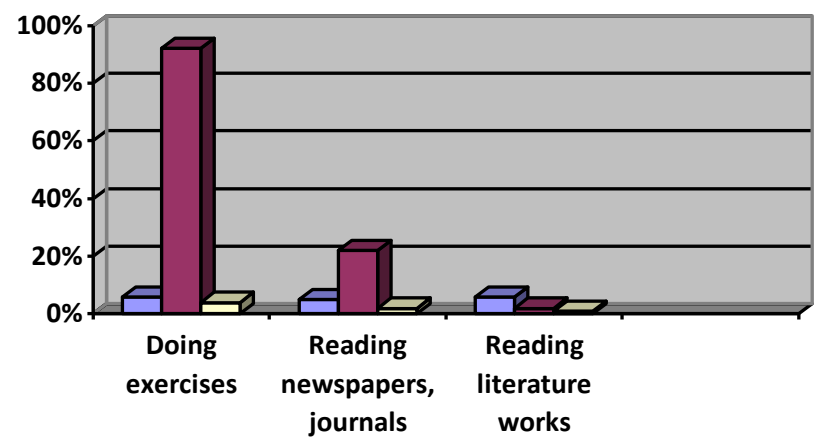

$\square$ Sometimes/rarely
$\square$ Often
$\square$ Always

1. Methods and frequency for improving reading skill outside classroom

Chart

\subsubsection{Writing Skill}

Generally, there seems to be a stark discrepancy among the three methods with students' priority to "writing on free topics". The investigation indicates that writing on free topics was widely accepted by English lessons (75\% of students). 69\% students got used to writing on free topics in order to build up their skill. This finding is congruent with the statement $[4,5]$. All of them insisted that more essays students wrote, the better writers they tended to be. On the contrary, the number of choices of reading English literature works is three times lower than for writing on free topics (34\% of students); a few students $(10 \%)$ had a habit of using this method.
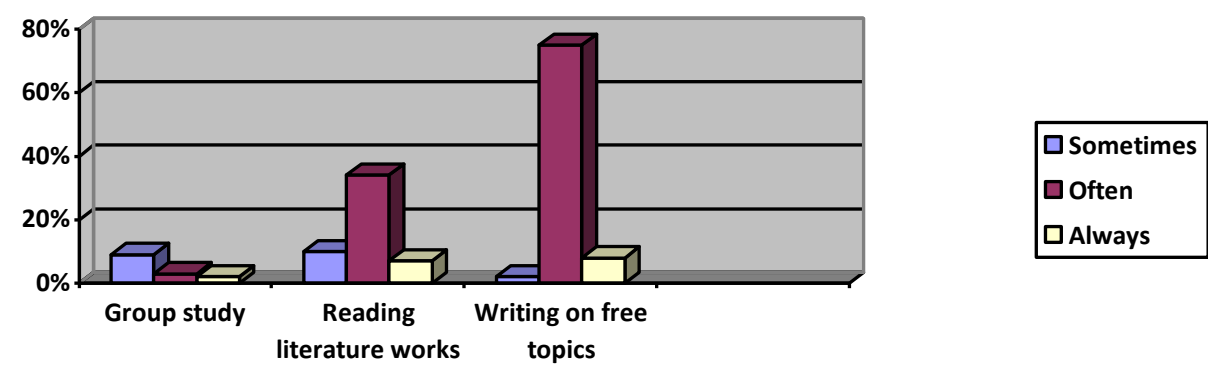

Chart2. Methods and frequency for improving writing skill outside classroom

\subsubsection{Listening Skill}

In general, students favored not only course books but also means of entertainment like watching TV and listening to songs to support their listening skill.

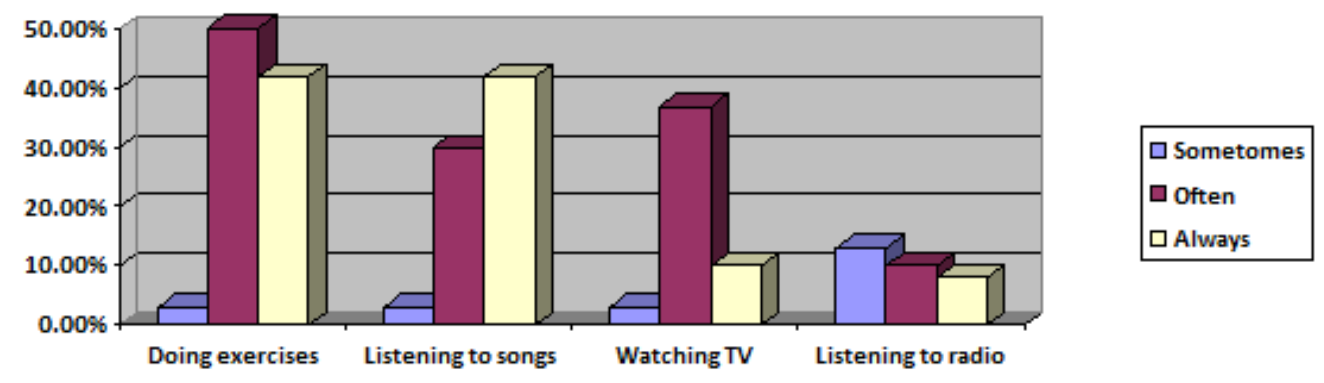


Chart3. Methods and frequency for improving listening skill outside classroom

Firstly, most of the students (95\%) regarded doing listening exercises as the most popular method. Its popularity was proved by the fact that $42 \%$ students did listening exercises with high frequency and $50 \%$ often spent time practicing this method. This indicates that students tended to do preparation exercises to polish listening skill. This conclusion goes in line with the findings [4]. She asserted that students' skills and performance could be effectively improved by doing further exercises. Moreover, TOEIC listening exercises is highly valued worldwide because of their international standard of language assessment. Secondly, nearly $75 \%$ of the students agreed that frequent listening to English songs enhanced their listening study. Finally, the number of students choosing listening to radio to improve listening skill is quite low (30\%) and only equals to half of those watching TV (48\%).

\subsubsection{Speaking Skill}

The majority of the students $(87,5 \%)$ considered self-talking the most valuable method and $80 \%$ of them had a habit of practicing this method regularly.

However, when it comes to speaking in front of other people such as talking to native speakers, joining speaking clubs or groups and communicating in daily life, the number of students who preferred those methods is lower (with about $25 \%$ of students respectively) than that for self-talking and using mass media. Nevertheless, there are particularly fewer students practicing those methods regularly. The possible reason could be students' inactive and apathetic way of learning. They demonstrated that students were passive and practiced speaking little English in front of other people because they were not confident.

\section{DISCUSSION}

This conclusion for learning English outside classroom disconfirms what Le [2] had explored. He proved that the efficiency of learning methods was not recognized by most learners of English. In reality, studying English at university requires a wide range of effective methods, of which all students should be fully conscious.

This result of improving reading skill outside classroom disconfirms the findings [3] in which they insisted that both literature works and journals were necessary for students to employ. The discrepancy may be resulted from students' passive learning method which might lead to the lack of practical reading skill in the future.

All research for improving writing skill outside classroom proved that reading English materials was a valuable tool which should be combined with writing to improve writing ability because those materials were copious sources of vocabulary, grammar and styles. Besides, not many students favored group working outside classroom. It reveals that students did not take group study into consideration and could not recognize its real efficiency.

Method for improving listening skill outside classroom seems that melodies could lead students to a good state of understanding spoken English. This confirms the research in "How to learn English" [5]. They stated that listening comprehension could be developed thanks to getting lyrics and singing after the artists because listeners got familiar with sounds, voices, intonations and rhythms of native speakers. Moreover, Santrock \& Halonen [6] had the same idea about songs, which could naturally expose learners to English, and their good effects on student's memory. The reason might be TV is more attractive than radio. This is congruent with studies of Centre for Independent Language Learning [7]. All their research deduced that students could understand more about body languages and topics through realistic programs on TV than radio.

This coincides with what Donald \& Kneale [3] and Gardner \& Jewler [8] found out. They stated that "self-talking" technique could easily improve student's spoken language outside classroom and bring practical benefit to the development of communicating ability. Furthermore, among $80 \%$ students who voted for advantage of mass media, $65 \%$ of students approved that frequent exposure to mass media was a component of success in mastering speaking skill. This goes in line with the recommendation in "Learning English through movies" [10]. In this article, mass media (TV, radio, etc.) played an important role in learning spoken English because learners could experience native speakers' real-life situation, useful language expressions and phrases for conversation. 


\section{CONCLUSiON}

To sum up, through this small-scale investigation, some of the most used methods to improve English skills outside classroom of students at Trade union University were discovered. On the whole, certain methods of learning four English skills have been regularly applied by most of the students. For example, the students frequently practiced TOEIC exercises to enhance receptive skills (reading and listening). Furthermore, they regularly imposed upon mass media or self-talking in English to cultivate their writing and speaking capacity. Additionally, it was test format at university and time that affected their decision of selecting suitable methods the most. In addition, the other methods such as group-working, examined to be valuable for learning after school, were not reasonably evaluated. It is recommended that practicing English skills should involve active and flexible methods. They can boost their listening skill through means of entertainment, which is not only interesting but also very practical. Particularly, students should manage time reasonably to join English clubs and social activities to build up confidence and practical skills.

\section{REFERENCES}

[1] Wallace, T., Stariha, W. E., \& Walberg. H. J. (2009). Teaching speaking, listening, writing. Belgium: International Academy of Education.

[2] Le, H.H. (2019). Investigation into language learning strategies of different learners in Vietnam. Masters thesis, Vietnam.

[3] Donald, S. G., \& Kneale, P. E. ( $2^{\text {nd }}$ ed.) (2011). Stucy skills for language students. London: Arnold Publisher.

[4] Kanar, C. C. (2001). The confident student (5 $5^{\text {th }}$ ed.). Boston: Houghton Muffin.

[5] How to learn English. (2001) from http://www.world- english.org/how_to_leam_english.htm. (Retrieved October 10, 2020)

[6] Santrock, J. W, \& Halonen, J. S. (2 $2^{\text {nd }}$ ed.) (2009). Your guide to college success: strategies jar achieving your goals. Belmont: Wadsworth.

[7] Centre for Independent Language Learning. (2010). Listening. (Retrieved October 10, 2020)

[8] Gardner, J. N., \& Jewler, A. J. (2000). Your college experience: strategies for success (4 ed.). Belmont: Wadsworth.

Citation: MA. Trinh Thi Thanh Thuy, MA. Nguyen An Giang. "Methods of Learning English Skills outside Classroom of Students: A Case Study in Vietnam" International Journal of Humanities Social Sciences and Education (IJHSSE), vol 7, no. 12, 2020, pp. 24-27. doi: https://doi.org/10.20431/2349-0381.0712003.

Copyright: () 2020 Authors. This is an open-access article distributed under the terms of the Creative Commons Attribution License, which permits unrestricted use, distribution, and reproduction in any medium, provided the original author and source are credited. 